\title{
Some Effects of Drug Abuse On The Psychosocial Adjustment Among University Students
}

\author{
- BATOUL M. M. EL HILO \\ (PhD of Psychology)
}

King Saud University / Department of Psychology

Kingdom of Saudi Arabia:

\section{Introduction}

Adjustment is often used synonymously with the term adaptation. In practice; "Adjustment is concerned with matching or current abilities to the demand of living" (Grasha et al., 1980:48). It depends on the relationship between the situation and the individual's personal characteristics: "Our level of Adjustment depends on our appraisal of situation and our abilities to handle it". (Smith et al., 1982: 477).

For Eysenk et al., (1975) adjustment is defined as:

1. A state in which the needs of the individual on the one hand and the claims of the environment on the other are fully satisfied.

2. A process by which this harmonious relationship can be attained.

The present paper has adopted Weiten (1983) definition of adjustment that, Effects of drug abuse From a social point of view drugs abuse "reflect the individual's inability or lack of willingness to function within the system" (Alfred, 1985:353). "Drug misuse damages communities in two main ways. First, it can cause underachievement, ill health, suffering, and even death to those individuals who misuse them. Furthermore, it is a problem for the whole community, including the abusers, both in lost productivity and particularly because of drig-related criminal activity and the fear that this cause" (HMOS, 1995:37). Moreover, Ofsted (1997:1) explain that "the effects of drug misuse reach beyond the drug user to the family, friends and communities: accidents affect not only the drug user, but many others and a complex relationship exist between drug and crime." Alcohol use has been linked to fights, destroyed property, 


\section{Some Effects of Drug Abùse On The Psychosocial Adjustment Among University Students}

academic and occupational problems and trouble with law enforcement officials.

Medically, alcohol abusers are at increase risks for liver, esophagus, nasopharynx, and larynx cancer. Stall (1986) explains that drug misuse contributes to human immunodeficiency syndrome infection and sexual transmitted diseases, directly (through sharing needles) or indirectly (because of using alcohol and other drugs that can impair judgment and reduce inhibition about engaging in sexual intercourse. Cocaine can cause disability or death from myocardial infractions, cardiac arrhythmais and strokes (Ibid.). In addition, eating disorders, such as anorexia nervosa and bulimia, have been associated with cocaine abuse (UN, 1992). Many drug misusers do not suffer serious illness, but through self-neglect and theirs risk-taking lifestyle, place a heavy burden on hospitals and general practices (HMOS, 1995). Stephen \& Miller (1987) explain that stimulants do affect the brain chemistry, because the smoke drug contains many of the toxic elements. Since the drug smoke retains in the lungs longer than tobacco, Stephen \& Miller, argue that concerns have been raised about its effects on the respiratory system.

Drug abuse "adversely affects self-esteem and predisposes to lack of success and productivity in later life (Alfred, et al. 1985: 354).

- Jones (1978) has summarized the psychosocial effects of marijuana as follows:

Emotionally, the drug seems to elevate mood by creating a mild sense of euphoria and by reducing feelings of tension

Cognitively, it distorts one's sense of time, enhances -one's sense of humor, intensifies one's concentration and leads one to see proundity (prove) in everyday observations.

Subjectively, it is reported that marijuana increases one's interest in both food and sexual activity

Perceptyally, it seems to. increase one's enjoyment of both sights and sounds.

The mechanism by which this is accomplished is not confirmed by Jones, but some studies Duek (1987), Klonoff

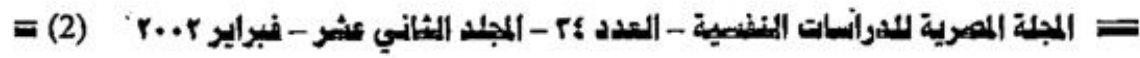


= D\BATOUL M. M. EL

(1974), Smith et al (1982) show that the drug does not make people more sensitive to incoming stimulation.

Marijuana's effects on the young female are also startling; researchers have found serious abnormalities in the rhesus monkey, an animal with menstrual cycle similar to that of human female (Dr. Ethel Sassenrath, UC Davis Primate Center). Its Social \& emotional changes could be summarized as

1. Mood alteration-changes and "swings" in mood-from euphoria and gregariousness to irritability; anxiety, violence, bizarreness, depressed mood, outbursts of anger.

2. Sudden changes in friends, disdain for old friends, new people calling, frequenting new hangouts, people stoping by for short periods

3. Drop in school performance, truancy, resentment toward teachers, avoiding schoolwork (or not bringing books home) lack of interest and concentration span in school and generally ("amotivational syndrome")

4. Legal problèms-late hours, traffic violations, assaulativeness, disrespect for police, eventually possession of paraphemalia and drugs

5. Resentment toward all authority

6. Flagrant disregard for all rules-school, home, and legal.

\section{Method}

\section{Sample:}

The sample for the present study was selected from the population of one Governmental and one Private Universities. These Universities are considered as having high population compared to other Universities in Khartoum State. 177(58.4\%) students from Governmental University, and 161(53.13\%) from Private University were selected. All Final forms in Arts and Science specializations were selected from final forms. Respondents with any uncompleted data were excluded from the further analyses, yielding a final sample of 303 respondents (180 males and 123 females). For the sake of confidintiality of information names of universities are not mentioned in the present study.

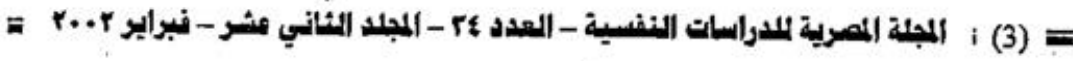


Some Effects of Drug Abuse On The Psychosocial Adjustment Among University Students Instruments

The following self-report Inventories were used in the present study. This type of Inventories were used because, they are economical with regard to time and resources, and provide greater anonymity than face-to-face interviews.

(1) self-report questionnaire

It is fair to mention here that the self report questionnaire was developed from a similar one which was adopted by the WHO Methodology for Students Drug use Surveys' by Smart et al., (1987). However, this self report questionnaire in the present srudy has been translated, validated and tested among 30 University students under conditions comparable to those anticipated in the final study. In the present study steps were taken to assure respondents of confidintiality and to encourge truthfulness

(2) Psychosocial Hugh M. Bell Psychosocial adjustment Inventory (Translated version by Nagati, 1961)

In three universities in Khartoum State the procedure of the standardization of Hugh M. Bell Psychosocial Adjustment Inventory was carried. For assessing the temporal stability and internal consistency reliabilities of the scale, a sample of 50 university students had been drawn.

Test reliability has been computed using "Kuder-Richardson 20 Formula" (Furgeson, 1981: 438) The computed r was $=.946$. The method of presenting norm-referenced scores (normative data) in the present study is the tabular method (Conversion table). Students with T scores of 41-59 are considered as students with average (normal) psychosocial adjustment, students with $T$ scores of $60-71$ and above are considered as psychosocially maladjusted students.

Results

Means and standard deviations for each measure, drug users and nonusers, and for the total sample regarding the dependant variables, are presented (Table 1-6).

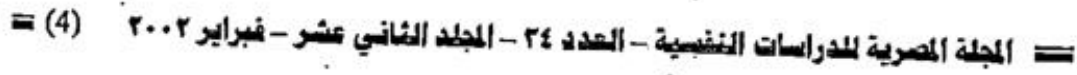


= D\BATOUL M. M. EL

Table (1)

Distribution of the Sample, $N=303$

\begin{tabular}{||c|c|c|c|c|c|c|c|}
\hline \multicolumn{4}{|c|}{ Govemmental University } & \multicolumn{4}{c|}{ Private University } \\
\hline \multicolumn{2}{|c|}{ Arts } & \multicolumn{2}{c|}{ Sciences } & \multicolumn{2}{|c|}{ Arts } & \multicolumn{2}{|c|}{ Sciences } \\
\hline Male & Female & Male & Female & Male & Female & Male & Female \\
\hline 54 & 39 & 52 & 16 & 48 & 41 & 26 & 27 \\
$17.82 \%$ & $12.87 \%$ & $17.16 \%$ & $5.28 \%$ & $15.84 \%$ & $13.53 \%$ & $8.58 \%$ & $8.91 \%$ \\
\hline
\end{tabular}

Table (1) shows the distribution of respondents in relation to sex, university type, and faculty specialization.

Table (2) distribution of Drug-users

Among University Students, $\mathrm{N}=140$

\begin{tabular}{|c|c|c|c|c|c|c|c|c|c|c|c|}
\hline \multicolumn{2}{|c|}{$\begin{array}{l}\text { Governmenta } \\
\text { I University }\end{array}$} & \multicolumn{2}{|c|}{$\begin{array}{l}\text { Private } \\
\text { University }\end{array}$} & \multicolumn{2}{|c|}{ Arts } & \multicolumn{2}{|c|}{ Sciences } & \multicolumn{2}{|c|}{ Male } & \multicolumn{2}{|c|}{ Female } \\
\hline User & $\begin{array}{l}\text { Non } \\
\text { user }\end{array}$ & user & $\begin{array}{l}\text { Non } \\
\text { user }\end{array}$ & Users & $\begin{array}{l}\begin{array}{l}\text { Non } \\
\text { user }\end{array} \\
\end{array}$ & User & $\begin{array}{l}\text { Non } \\
\text { user }\end{array}$ & user & $\begin{array}{l}\text { Non } \\
\text { user }\end{array}$ & Users & $\begin{array}{l}\text { Non } \\
\text { user }\end{array}$ \\
\hline $\begin{array}{r}70 \\
43.5 \% \\
\end{array}$ & $\begin{array}{c}91 \\
56.5 \% \\
\end{array}$ & $\begin{array}{c}70 \\
49.3 \% \\
\end{array}$ & $\begin{array}{c}72 \\
50,7 \% \\
\end{array}$ & $\begin{array}{c}83 \\
45.6 \% \\
\end{array}$ & $\begin{array}{c}99 \\
54,4 \%\end{array}$ & $\begin{array}{c}57 \\
47.1 \%\end{array}$ & $\begin{array}{c}64 \\
52.9 \% \\
\end{array}$ & $\begin{array}{c}100 \\
557 \% \\
\end{array}$ & $\begin{array}{c}80 \\
44,4 \%\end{array}$ & $\begin{array}{c}40 \\
32.5 \%\end{array}$ & $\begin{array}{c}83 \\
67.5 \% \\
\end{array}$ \\
\hline
\end{tabular}

Table (2) shows the distribution of drug-users in relation to sex, university type, and faculty specialization.

Table (3)

T-Test, Mean, standard deviation \& Differences of Means on Psychosocial adjustment

Inventory of Drug users and Non-users, $\mathrm{N}=303$

\begin{tabular}{|l|l|l|l|l|l|l|l|}
\hline Adjustment Dornains & \multicolumn{1}{|c|}{ Groups } & $\begin{array}{l}\text { Degree of } \\
\text { Freedom }\end{array}$ & \multicolumn{1}{|c|}{ Mean } & S.D. & $\begin{array}{l}\text { Stand } \\
\text { Enor }\end{array}$ & $\begin{array}{c}\text { T. } \\
\text { Value }\end{array}$ & $\begin{array}{l}\text { Level of } \\
\text { Sig.(05) }\end{array}$ \\
\hline Emotional & Non-users & 301 & 17.4908 & 5.829 & .457 & -16.67 & Sig. \\
& Users & & 27.7571 & 3.929 & .332 & & \\
\hline Health & Non-users & 301 & 18.7791 & 5.718 & .448 & -16.50 & Sig. \\
& Users & & 27.6643 & 3.535 & .299 & & \\
\hline Home & Non-users & 301 & 19.5521 & 5.738 & .449 & -14.31 & Sig. \\
& Users & & 27.3214 & 3.110 & .263 & & \\
\hline Social & Non-users & 301 & 17.3252 & 5.230 & .410 & -18.95 & Sig. \\
& Users & & 27.5500 & 3.950 & 334 & & \\
\hline General & Non-users & 301 & 73.1472 & 16.434 & 1.287 & -23.02 & Sig. \\
& Users & & 110.2929 & 10.479 & .886 & & \\
\hline
\end{tabular}

Tabulated $\mathrm{t}=1.658$

Table (3) shows the differences between the scores of the drug users and non-users in the Psychosocial Adjustment Inventory. It appears that drug users have significantly lower levels of psychosocial adjustment. 
Some Effects of Drug Abuse On The Psychosocial Adjustment Among University Students

Table (4)

T-Test, Mean, standard deviation \& Differences of Psychosocial adjustment Scores of Males/Females students Drug users, $N=140$

\begin{tabular}{|c|c|c|c|c|c|c|c|c|}
\hline $\begin{array}{l}\text { Adjustment } \\
\text { Domains }\end{array}$ & Groups & No. & $\begin{array}{c}\text { Degree } \\
\text { of } \\
\text { Freedom }\end{array}$ & Mean & S.D. & $\begin{array}{l}\text { Stand } \\
\text { Error }\end{array}$ & $\begin{array}{c}\text { T. } \\
\text { Value }\end{array}$ & $\begin{array}{c}\text { Level of } \\
\text { Sig } \\
(.05)\end{array}$ \\
\hline Emotional & $\begin{array}{l}\text { Males } \\
\text { Females }\end{array}$ & $\begin{array}{l}100 \\
40\end{array}$ & 138 & $\begin{array}{l}28.250 \\
26.525 \\
\end{array}$ & $\begin{array}{l}3.491 \\
4.679 \\
\end{array}$ & $\begin{array}{l}.349 \\
.740 \\
\end{array}$ & 2.39 & Sig \\
\hline Health & $\begin{array}{l}\text { Males } \\
\text { Females }\end{array}$ & $\begin{array}{l}100 \\
40\end{array}$ & 138 & $\begin{array}{l}27.425 \\
27.760 \\
\end{array}$ & $\begin{array}{l}3.376 \\
3.941 \\
\end{array}$ & $\begin{array}{l}.338 \\
.623 \\
\end{array}$ & .51 & Not Sig \\
\hline Home & $\begin{array}{l}\text { Males } \\
\text { Females }\end{array}$ & $\begin{array}{l}100 \\
40 \\
\end{array}$ & 138 & $\begin{array}{l}27.560 \\
26.725\end{array}$ & $\begin{array}{l}3.013 \\
3.305 \\
\end{array}$ & $\begin{array}{l}.301 \\
.523 \\
\end{array}$ & 1.44 & Not Sig \\
\hline Social & $\begin{array}{l}\text { Males } \\
\text { Females } \\
\end{array}$ & $\begin{array}{l}100 \\
40 \\
\end{array}$ & 138 & $\begin{array}{l}27.980 \\
26.475 \\
\end{array}$ & $\begin{array}{l}3.848 \\
4.045 \\
\end{array}$ & $\begin{array}{r}.385 \\
.639 \\
\end{array}$ & 2.06 & Sig \\
\hline General & $\begin{array}{l}\text { Males } \\
\text { Females }\end{array}$ & $\begin{array}{l}100 \\
40\end{array}$ & 138 & $\begin{array}{l}111.55 \\
107.15 \\
\end{array}$ & $\begin{array}{l}9.845 \\
11.45 \\
\end{array}$ & $\begin{array}{l}984^{\circ} \\
1.81\end{array}$ & 2.28 & Sig \\
\hline
\end{tabular}

\section{Tabulated $\mathrm{t}=1.658$}

Table (4) shows significant differences between males and females drug-users in regard to "Social adjustment" and "Emotional adjustment" domains, and the difference between the two groups in the Social and Emotional domain was not significant. Female drug users are psychosocially better adjusted than males' drug users, having lower means with relation to general, social and emotional psychosocial adjustment.

Table (5)

T-Test, Mean, standard deviation \& Differences of Psychosocial adjustment Scores of the Private/Governmental Students Drug users, $\mathrm{N}=140$

\begin{tabular}{|c|c|c|c|c|c|c|c|c|}
\hline \begin{tabular}{|} 
Adjustment \\
Domaing
\end{tabular} & Groups & No. & D.F. & Mean & S.D. & $\begin{array}{c}\text { Stand } \\
\text { Enor }\end{array}$ & T. Value & Level of Sig \\
\hline \multirow{3}{*}{ Emotional } & Private & 70 & 138 & 28.2429 & 3.873 & .463 & & \\
& Govern & 70 & & 27.2714 & 3.952 & .972 & 1.47 & Not Sig \\
& mental & & & & & & \\
\hline \multirow{3}{*}{ Health } & Private & 70 & 138 & 28.8857 & 3.900 & .466 & & \\
& Govern & 70 & & 27.2429 & 3.099 & .370 & \multirow{2}{*}{ Not Sig } \\
\hline
\end{tabular}


= D\BATOUL M. M. EL

\begin{tabular}{|c|c|c|c|c|c|c|c|c|}
\hline Home & $\begin{array}{l}\text { Private } \\
\text { Govern } \\
\text { mental }\end{array}$ & $\begin{array}{l}70 \\
70\end{array}$ & 138 & $\begin{array}{l}27.3000 \\
27.3429\end{array}$ & $\begin{array}{l}3.351 \\
2.874\end{array}$ & $\begin{array}{l}.460 \\
.343\end{array}$ & .03 & Not Sig \\
\hline Social & $\begin{array}{l}\text { Private } \\
\text { Govern } \\
\text { mental }\end{array}$ & $\begin{array}{l}70 \\
70\end{array}$ & 138 & $\begin{array}{l}27.5571 \\
27.5429\end{array}$ & $\begin{array}{l}4,468 \\
3.387\end{array}$ & $\begin{array}{l}.534 \\
.405\end{array}$ & .02 & Not Sig \\
\hline General & $\begin{array}{l}\text { Private } \\
\text { Govern } \\
\text { mental }\end{array}$ & $\begin{array}{l}70 \\
70\end{array}$ & 138 & $\begin{array}{r}111.1857 \\
109.4000\end{array}$ & $\begin{array}{l}12.629 \\
7.752\end{array}$ & $\begin{array}{l}1.509 \\
.927\end{array}$ & $\begin{array}{l}1.01 \\
. \\
\end{array}$ & Not Sig \\
\hline
\end{tabular}

Tabulated $\mathrm{t}=1.658$

Result (Table, 5) shows no significant differences between the scores (on the Psychosocial Adjustment Inventory) of the students (drug users) enrolled in Governmental University and their counterparts enrolled in Private University not only in relation to their psychosocial adjustment domains but also to the general psychosocial Adjustment.

\section{Table (6)}

T-Test; Mean, standard deviation \& Differences of Psychosocial adjustment Scores of the Arts/Sciences Students Drug users,

$\mathrm{N}=140$

\begin{tabular}{|c|c|c|c|c|c|c|c|}
\hline $\begin{array}{c}\text { Adjustment } \\
\text { Domains }\end{array}$ & Groups & $\begin{array}{l}\text { Degree } \\
\text { of } \\
\text { Freedom }\end{array}$ & Mean & S.D. & $\begin{array}{l}\text { Stand } \\
\text { Error }\end{array}$ & T. Value & $\begin{array}{c}\text { Level of } \\
\text { Sig }\end{array}$ \\
\hline Emotional & $\begin{array}{l}\text { Arts } \\
\text { Sciences }\end{array}$ & $\begin{array}{l}83 \\
57\end{array}$ & $\begin{array}{l}27.5181 \\
28.1053\end{array}$ & $\begin{array}{l}4.241 \\
3.431\end{array}$ & $\begin{array}{l}.465 \\
.454\end{array}$ & .87 & Not Sig \\
\hline Health & $\begin{array}{l}\text { Arts } \\
\text { Sciences }\end{array}$ & $\begin{array}{l}83 \\
57\end{array}$ & $\begin{array}{l}27.5422 \\
27.8421\end{array}$ & $\begin{array}{l}3.703 \\
3.299\end{array}$ & $\begin{array}{l}.406 \\
.437\end{array}$ & .99 & Not Sig \\
\hline Home & $\begin{array}{l}\text { Arts } \\
\text { Sciences }\end{array}$ & $\begin{array}{l}83 \\
57\end{array}$ & $\begin{array}{l}27.1566 \\
27.5614\end{array}$ & $\begin{array}{l}3.248 \\
2.909\end{array}$ & $\begin{array}{l}.356 \\
.385\end{array}$ & .76 & Not Sig \\
\hline Social & $\begin{array}{l}\text { Arts } \\
\text { Sciences }\end{array}$ & $\begin{array}{l}83 \\
57\end{array}$ & $\begin{array}{l}27.3855 \\
27.7895\end{array}$ & $\begin{array}{l}4.370 \\
3.266\end{array}$ & $\begin{array}{l}.480 \\
.433\end{array}$ & .59 & Not Sig \\
\hline General & $\begin{array}{l}\text { Arts } \\
\text { Sciences }\end{array}$ & $\begin{array}{l}83 \\
57\end{array}$ & $\begin{array}{l}109.6024 \\
111.2982\end{array}$ & $\begin{array}{l}10.995 \\
9.684\end{array}$ & $\begin{array}{l}1.207 \\
1.283\end{array}$ & .94 & Not Sig \\
\hline
\end{tabular}

Tabulated $\mathrm{t}=1.658$

Result (Table, 6) shows no significant differences between the scores (on the Psychosocial Adjustment Inventory) of the university students (drug users) who are specialized in Arts and their counterparts who are specialized in Sciences. It could be stated here that students (drug-users) specialized in Arts and

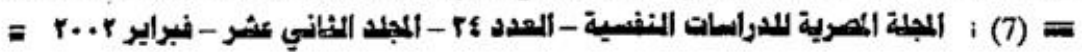


Some Effects of Drug Abuse On The Psychosocial Adjustment Among University Students

Students specialized in Science, have the same levels of Psychosocial Adjustment.

\section{Discussion}

The present study was designed to examine the effect of drug use on the psychosocial adjustment among university students using self-report inventories.

Regarding the hypothesis and the results by the study, nondrug users have higher levels of psychosocial adjustment (lower mean scores) than drug users. Accordingly, it could be stated here that drug use does affect the psychosocial adjustment among university students who use drugs.

The confirmed significant effects of the drug on the psychosocial adjustment among university students may be attributed to their inability to cope with various factors, such as the type of university, sex, specialization of the study, personality, attitudes, home environment, social and emotional adjustment, experience and beliefs. In this issue, the present finding substantiates the findings of Walman (1964) that people
differ in their ability to cope with the environment.

The fact that males outnumbered females in drug usage (Table,

2) conforms to Suchum (1968) and Grossman et al (1971) who consistently find that males do much more drug experimentation than females. Here it could be stated that the use of drug by males might be regarded as an insignia of masculinity. In addition, to the fact that in Sudanese religious moods, tradition of upbringing and discipline, and family rules enforce and impose special types of rules and standards on the conduct of females. As a result the Sudanese society frowns very much on female drug use and females themselves feel afraid of being seduced while being under the effect of the drug. However, this assumption does not mean, that there are no female drug-users that like members of the male sex use drugs when they feel depressed and unhappy or could not be able to cope with the environment. In part the differences between the two groups could be attributed to the cultural differences in the training of the two sexes and in part it agrees with Grinder (1973) that the drug effect is consistent with $=(8)$

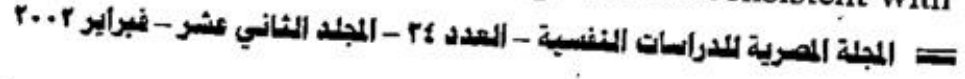


maladjustment, and that females have more to lose than males. Therefore, it is quite obvious to find that the incidence of drug abuse among males in the present study is higher than that among females, and that female drug-users in-spite of their wrong behavior they do not want to be losers so they are psychosocially better adjusted than males.

Table (3) shows a significant difference between drug users and non-users not only in the different psychosocial domains but also in the general psychosocial adjustment.

A close inspection of the result in table (4) reveals that female drug users have higher levels of adjustment than male drug users in respect to the "Social" and "Emotional" domains. Furthermore, the data reveals insignificant differences between male-drug abusers and female drug abusers in the 'Health domain' and 'Home domain'. It could be stated that male and female drug abusers have the same levels of 'Home' and 'Health' maladjustment.

Concerning the differences between males and females drug abusers in the 'social domain', it could be viewed that, in the traditional Sudanese socio-cultural environment, it is expected that males and females share different sorts of experiences and are exposed to varying environmental stimuli. Therefore, they may be having different attitudes, values, and adjustment patterns. It is also reasonable to find that they also vary in relation to the process of person-social adjustment.

It is too early, however, to generalize this finding. Thus, it is necessary in view of certain factors influencing the sample, that further research be conducted in order that more can be learned about these domains.

Interestingly, it may be inferred from the result in table (4) that differences in the 'Emotional domain' is significantly in favor of females. This difference could be attributed to sex role socialization (people who are motivated to act like 'males' or 'females' will avoid behaviors that are inappropriate for their sex). For example in the Sudanes a culture males are taught to avoid making themselves vulnerable and to conceal their doubts,

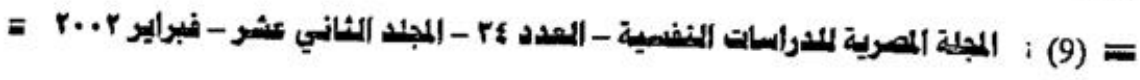


fears, and anxieties. Thus they are seen by the society as unemotional, aggressive, and competent. In addition males learn early that it is unmanly to display emotions. They are obliged to hide many feelings and control their emotions. Ideally, it is obvious that their responses sometimes appear to be falsified and tend to affect their emotional adjustment. This seems to be true in consideration of the sample in the present study. However, this concept is in line with Delega and Janda (1978) that the traditional male role often prevents men from sharing their feelings and emotions with others and that men are seen as acting logically and rationally. They can intentionally hide their dominant position in male-female relationships. In Addition emotional over control is just as undesirable as lack of control, and healthy people are always responding in a calculated and rational manner (Ibid).

Results (Table, 5) show insignificant differences between the drug abusers in Governmental University and their counterparts in Private university. This suggests that there is a degree of commonality in the non-specific factors or personality profile of the two groups.

Table (6) shows insignificant differences between drug users specialized in Arts and those specialized in Sciences regarding their psychosocial adjustment. This may be interpreted by saying that, from the temperamental point of view; both groups possess the same 'non-specific factors' that predisposed them to the same level of psychosocial maladjustment.

It could be suggested here that additional studies is needed for factorial analysis in relation to drug' effects on psychosocial adjustment in relation to their sex, age, socioeconomic, faculty specialization and university type.

\section{References}

1- Alfred S. Friedman, Nita Glickman, \& Arlene Utada (1985)

"Does Drug \& Alcohol Use Lead to Failure to Graduate from High School?" Journal of Drug Education, Volume, 15(4) Baywood, Publishing co.

$=$ 
- D \BATOUL M. M. EL

2- Darley, John John, Glusksberg, Kinchla; \& Ronald, A. (1984) Psychology, 2nd Prentice- Hall, Inc.

3- Derlega, V. Janda \& Chaikin, A. L. (1976) "Norms Affecting Self-Disclosure in Men \& Women", Journal of Consulting and Clinical Psychology.

4- Dusek Dorothy E., and Girdano, Daniel, A. (1987) Drugs A factual Account Newberg Award Record.

5- Walman, B. (1964) Dictionary of Behavioral Science, NT Reinhold, Co:

6- Eysenck, W. J. Arnold and R. Meili (1975) Encyclopedia of Psychology, Volume 1-2, Publishing Search Press.

7- Grasha, Anthony F. (1980) Psychology of Adjustment and Competence, An Applied Approach, Winthrop Publishers, Inc.

8- Grinder, Robert E. (1975) Studies in Adolescene: A Book of Readings in :Adolescent. Development 3rd Edition, Mac Millan Publishing Co., Inc

9- Grossman, J. C., Goldestien \& Eiseman, (1973) "Openness to Experience and Marijuana Use in High schools Students" Journal of Consulting and Clinical Psychology, XLL, 78-85.

10- HMSO (1995) Taking Drugs Together, HMSO Publications Center.

11- Institute for the Study of Drug Dependence (ISDD) (1982)

Facts and Feelings About Drugs But Decisions Situations, Teachers' Manual; A Drug Education Manual Outlying A Short Course for Use in Secondary School.

12- Jones, C. (1981) Criminology, Mac Millan Publishing Co. Inc.

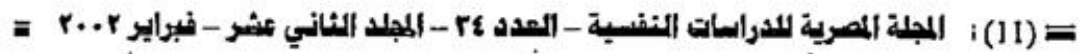


Some Effects of Drug Abuse On The Psychosocial Adjustment Among University Students

13- Klonoff H. (1974) "Marijuana, and Driving in Real Life Situations" Science, 186. 317-324.

14- OFSTED (1997) The Contribution of Youth Services to Drug Education, HMSOC.

15-Ray, O. (1983) Drug , Society and Human Behaviour, The C. V. Mosby Company.

16- Smith, Ronald, E. Sarason, Irvin G. \& Sarason Barbara R. (1982) Psychology, The Frontiers of Behavior, 2nd Edition, Harbor Row Publishers, Inc:

17-Stall, R., (1986) "Alcohol and Drug Use During Sexual Activity and Compliance With Safe".Sex Guidelines for AIDS" Behavioural Research Project Health Education, Q 13: pp. 359-371.

18- Stephen Powers, and Christine. E. M. (1987) "Effects of A Drug Education Program on Third and Fourth Grade Pupils" Journal of Drug Education, ISSN, 0090-1482, Volume 33 pp. 25-30, Fall.

19- UNECEF (1992) Information On Drug Demand Reduction; European Prevention Assessment System.

20- Suchum (1968) "The Hang-Loose, Ethnic and Sprit of Drug Use" , Journal of Health and Social Behavior, $1 \mathrm{X}, 146-155$. 